\title{
SEED IMPROVEMENT BY SELECTION AND INVIGORATION
}

\author{
A.A.POWELL \\ Dept. of Agriculture, University of Aberdeen, Aberdeen, Scotland, UK.
}

\begin{abstract}
The basis of differences in seed quality are described for two groups of crops, grain legumes and vegetables and approaches to the improvement of quality are proposed. In grain legumes the major factors affecting seed quality are imbibition damage, seed ageing and their interaction. It is proposed that use of seed vigour tests, specifically the electrical conductivity test, to identify the incidence of imbibition damage and ageing allows the selection of seed lots for sale and for use under different field conditions. Alternatively in grain legume species in which there is a genotypic influence on predisposition to imbibition damage the approach to seed improvement may lie through selection in breeding programmes. Thus identification of testa characteristics that favour slow imbibition would enable selection for these characteristics. Seed ageing is also the major cause of reduced seed quality in vegetable species, leading to slow and asynchronous germination. An approach to their seed improvement has been the development of seed invigoration treatments based on seed hydration. The principle of these treatments is described and several treatments outlined, with emphasis being given to aerated hydration, a treatment completed within $36 \mathrm{~h}$. The physiological basis of improvement by invigoration is discussed. Key Words: grain legumes, vegetables, vigour, imbibition damage, ageing, testa pigmentation, invigoration treatments, metabolic repair
\end{abstract}

\section{SELEÇÃO E ENVIGORAMENTO COMO TÉCNICAS PARA O APRIMORAMENTO DO DESEMPENHO DE SEMENTES}

RESUMO: Neste trabalho, são descritas diferenças básicas na qualidade de sementes de leguminosas e hortaliças, e propostos procedimentos para a melhoria de seu desempenho. Os principais fatores que afetam a qualidade de sementes de leguminosas são as injurias durante a embebição, o envelhecimento e a interação entre esses fatores. Considera-se que a utilização de testes de vigor, principalmente o de condutividade elétrica, para a identificação de injurias durante a embebição e o grau de envelhecimento, permite a seleção de lotes para a comercialização e uso sob diferentes condições de campo. A alternativa, em leguminosas, onde há influência do genótipo ou maior sensibilidade a injurias por embebição, seria a obtenção de materiais com sementes de melhor qualidade através de seleção dirigida durante os trabalhos de melhoramento genético. Desta forma, a identificação de características do tegumento que possam favorecer a embebição lenta, permite a seleção dirigida para essas características. O envelhecimento da semente, também problemático em sementes de hortaliças, determinando a redução da velocidade e a desuniformidade de germinação, pode ser atenuado com a utilização do condicionamento fisiológico ("envigoramento"), através da hidratação controlada das sementes. Nesse trabalho, descrevemse os princípios e os procedimentos para condução desse tratamento, enfatizando-se a hidratação sob aeração, durante 36 horas. Discute-se, também, a base fisiológica da melhoria da qualidade através de tratamentos condicionadores.

Descritores: sementes, leguminosas, hortaliças, vigor, injúrias durante a embebição, envelhecimento, pigmentação do tegumento, envigoramento, reparo metabólico

\section{INTRODUCTION}

This paper will review the major causes of seed quality in two groups of crops, grain legumes and vegetables. Evidence in support of two approaches to the improvement of seed quality, selection in grain legumes and the invigoration of vegetable seeds, will then be presented. 


\section{SEED QUALITY IN GRAIN LEGUMES IMBIBITION DAMAGE}

The basic phenomenon: Imbibition damage was first observed in peas, when the cotyledons of seeds that had been imbibed with the testa removed (i.e. as embryos) failed to stain with the vital stain 2, 3, 5 triphenyl tetrazolium chloride (Powell \& Matthews, 1978). This apparent cell death was attributed to rapid water uptake into the outer cells of the cotyledons, leading to disruption of cell membranes and resulting in high solute leakage from the embryos, reduced respiration and germination and a decline in both the transfer of food reserves from the cotyledons to the growing axis and the growth rate of the surviving seedlings (Powell \& Matthews, 1978). The extent of damage to the cells of the cotyledons was confirmed in several grain legume species by the extensive loss of both cytosol and cytosol-organelle enzymes from imbibing embryos into the surrounding solution (Duke \& Kakefuda, 1981).

Imbibition damage has since been observed in Phaseolus (Powell et al.,1986b), soybean (Semple, 1981; Oliveira et al., 1983), field bean (Vicia faba) (Powell \& Matthews, 1980), chickpea (Cicer arietinum) (Legesse, 1991), cowpea (Vigna unguiculata) (Legesse \& Powell, 1982, Asiedu \& Powell, 1998) and longbean (Vigna sesquipedalis) (Abdullah, et al.,1991) leading to the proposal that it is common to all grain legumes (Powell et al., 1984).

Role of testa damage in grain legume seed quality: The significance of testa damage in intact seeds to seed quality was initially illustrated in scarified pea seeds (Powell \& Matthews, 1979) which showed increased dead tissue and solute leakage, indicative of imbibition damage, after imbibition. Subsequently the rate of imbibition of both commercial pea (Powell \& Matthews, 1980) and soybean (Oliveira et al, 1984) seed lots was related to the percentage of seeds having cracks in the testa. Seed lots with a high incidence of testa damage imbibed rapidly and showed extensive imbibition damage. Thus amongst seed lots of soybean the proportion of seeds with testa damage ranged from 7 to $88 \%$ with associated bulk conductivities rangeing from 28 to 48 mmho $\mathrm{cm}^{-1} \mathrm{~g}^{-1}$ (Oliveira et al., 1984 ). The mean emergence of these lots over two sowing dates ranged from 20 to $85 \%$, thus implicating imbibition damage as a direct cause of poor emergence. Indeed in peas, poor field emergence of low vigour lots has been associated with higher incidence of imbibition damage when they imbibed in field conditions. (Powell \& Matthews, 1980).

The reduced emergence associated with imbibition damage may result from physiological death due to imbibition damage or from increased predisposition to infection by soil-borne fungi. Matthews (1977) has described how infection by the soil-borne fungus Pythium is a major cause of emergence failure. Predisposition to infection may result from the incidence of dead tissue on the cotyledons which acts as a food base for fungal growth (Matthews, 1971) or from the leakage of solutes into the soil causing an increase in inoculum potential (Matthews, 1971; Perry, 1973). Both these are an outcome of imbibition damage and in soybean Matheson (1983) has reported greater infection by Pythium of seeds having cracked testae.

\section{Genotypic variation in susceptibility to imbibition}

damage: In a number of grain legume species, differences in field emergence, reflecting seed vigour,have also been observed between cultivars that differ in the pigmentation of the testa. Typically unpigmented cultivars give poor field emergence, whereas cultivars having pigmented testae emerge well. In Phaseolus vulgaris poor field emergence of 10 cultivars having unpigmented testae was associated with rapid imbibition and high incidence of imbibition damage (Powell et al., 1986a,b) compared with the high field emergence and slower imbibition of 21 cultivars having brown or black testae. Similar differences in field emergence and incidence of imbibition damage have been observed in chickpea (Legesse, 1991), long bean (Abdullah et al., 1991) and cowpea (Legesse \& Powell, 1992; Asiedu \& Powell, 1998).

However, in contrast to peas and soybeans, the incidence of testa damage did not explain differences in water uptake. In Phaseolus the major factor influencing imbibition was the degree of adherence of the testa to the cotyledons (Powell et al., 1986b). Thus in white cultivars, the loose adherence of the testa allowed water that had passed through the testa to move readily throughout the seed whilst the tight adherence of pigmented testae limited the movement of water through the space between the cotyledons and testa, resulting in slower imbibition. Adherence of the testa to the cotyledons was also the major factor contributing to the slow imbibition of Desi type chickpea (Legesse, 1991; Legesse \& Powell, 1996) although in this case testa permeability also influenced imbibition. In cowpea 
however, testa permeability apparently regulated the rate of imbibition (Legesse \& Powell, 1996).

The closeness of the association between testa pigmentation and the rate of imbibition damage has been illustrated using two approaches. Firstly, comparisons of imbibition in isogenic lines of peas, differing only in the gene for testa pigmentation (Powell, 1989) revealed that the rate of imbibition was reduced only when the dominant A gene for pigmentation was expressed. If expression of the $\mathrm{A}$ gene was suppressed by the recessive pallens gene, resulting in unpigmented testae, the rate of imbibition increased markedly. Secondly the rate of imbibition was examined in relation to the development of testa pigmentation during the maturation of the Phaseolus, cowpea and chickpea (Legesse \& Powell, 1996). Even in cultivars that are pigmented when mature, seeds are unpigmented when immature, and following harvest and drying at this immature stage, the seeds imbibed rapidly. However, as pigmentation developed and intensified the rate of imbibition rate declined so that at maturity the imbibition rate of pigmented cultivars was much slower than that of unpigmented cultivars. The role of pigmentation of the testa in reducing the rate of imbibition is still not entirely clear since it is associated with greater adherence of the testa to the cotyledons and/or testa permeability in different species. In addition pigmented testae have higher levels of lignins and tannins (Morrison et al 1995), waterproofing substances that may influence water uptake.

Ageing: Seed ageing is a well recognised cause of differences in seed quality in all species, including grain legumes (Matthews, 1980; Powell et al, 1984). Grain legumes, with their large cotyledons, provide an excellent example of how extensive deterioration can occur before the seed fails to germinate. Initially, membrane deterioration results in increased leakage from living cells of the cotyledons (Powell \& Matthews, 1977), then further deleterious subcellular changes lead to the development of areas of dead tissue and even greater solute leakage. However the seed retains the ability to germinate at this time. The increase in solute leakage is reflected in the electrical conductivity of seed soak water and therefore ageing provides a sound theoretical basis to the electrical conductivity test of seed vigour in grain legumes (Matthews \& Powell, 1981). Subsequently, as deleterious changes in enzymes, respiration, synthetic processes and macromolecules accumulate both within the cotyledons and the embryo axis, the seed fails to germinate (Powell et al., 1984).
Ageing is not however the only cause of increased solute leakage, increased leakage also results from imbibition damage. Thus the conductivity test reflects both the major causes of low vigour in grain legumes, ageing and imbibition damage. Furthermore, the incidence of seed ageing has been shown to increase the susceptibility of both peas (Powell, 1985) and cowpea (Asiedu \& Powell, 1998) to imbibition damage. It is envisaged that the membranes of aged seeds, whose integrity has been reduced by deterioration, are more susceptible to the physical damage resulting from rapid imbibition and hence show greater imbibition damage. Thus seeds that have low vigour as a result of ageing during storage will be more likely to have poor field emergence both due to seed deterioration and, also if soil conditions are wet, due to increased susceptibility to imbibition damage. The implications of this are most important in tropical climates in which storage conditions (high relative humidity and high temperature) lead to rapid deterioration, and where sowing occurs after onset of the rainy season.

Differences in the rate of seed ageing during storage are well recognised between species. However within grain legume species differences in deterioration between cultivars have also been associated with the presence/absence of testa pigmentation. In both Phaseolus vulgaris (Abdullah et al., 1993) and longbean (Abdullah et al., 1992) pigmented cultivars both took up moisture more slowly from the atmosphere and deteriorated more slowly than those with unpigmented testae when stored at $100 \%$ rh and $42^{\circ} \mathrm{C}$. Thus, during storage, the differences in water uptake illustrated earlier in water can also be seen from the humid atmosphere,leading to differences in the rate of deterioration.

\section{STRATEGIES FOR SELECTION TO IMPROVE SEED QUALITY}

Selection for sowing: The ability to identify differences in seed quality gives the opportunity to select seed lots for sowing under different field conditions, and in particular to avoid sowing low vigour lots in poor conditions. This forms the basis of seed vigour tests in which high and low vigour lots can be identified within commercial seed lots of a species. The electrical conductivity vigour test is one such test that has been applied to seed lots of vining or garden peas for many years, but which also identifies vigour differences amongst other grain legumes (Powell, 1986). The conductivity test satisfies the criteria of a vigour 
test as outlined by Matthews (1980). Firstly, it has a good theoretical background since it assesses solute leakage due to seed ageing, imbibition damage and their interaction. Secondly, it has a clear relationship with a measure of seed vigour, i.e. field emergence, and thirdly it is repeatable.

Assessment of vigour by conductivity can be used to identify and therefore select out seed lots having particularly low vigour and therefore avoid their sale. In addition in the UK, the OSTS of England and Wales has identified different ranges of conductivity that allow selection of high vigour lots for early sowing in poor conditions, but enable other lots to be sown later when field conditions are good (Matthews \& Powell, 1981).

Selection for breeding: Genotypic differences in response to imbibition damage, storage and reduced water availability have been linked with testa pigmentation although the nature of this response has only been examined in any detail for imbibition damage and storage. Thus the slower water uptake by pigmented cultivars is associated with higher seed quality than found in unpigmented cultivars. However in many cultivars, unpigmented cultivars are preferred for consumption and therefore there is demand for their seed. Opportunities may exist for improving the seed quality of unpigmented cultivars by selection in plant breeding programmes. Clear identification of the testa characteristic(s) associated with pigmentation that confer slow imbibition would allow its introduction into and selection within breeding lines having unpigmented testae. A more realistic option however could be the screening of white-coated breeding lines for those showing a slower rate of imbibition. These lines could then be incorporated into breeding programmes, followed by selection for slow imbibition.

\section{IMPROVEMENT OF SEED QUALITY BY INVIGORATION}

As in most species, the major cause of a decline in the vigour of vegetable seeds is believed to be seed ageing, a hypothesis that is supported by the ability of vigour tests based on ageing, such as controlled deterioration, to identify vigour differences (Matthews, 1980). Reduced seed vigour as a result of ageing can have a considerable effect on the timing of harvest, quality and yield of vegetable crops (FinchSavage, 1994). Seed invigoration treatments were initially developed to overcome these problems and to improve both the rate and uniformity of germination in vegetable species.

Approach to invigoration: The development of seed invigoration treatments really started with seed priming, as first described by Heydecker et al. (1973). Priming aimed to control seed hydration so that all seeds reached the same stage of germination before sowing, so that subsequent germination was rapid and synchronous. This was achieved by allowing seeds to imbibe from a solution of polyethylene glycol (PEG) such that imbibition ceased when the seed water potential equalled that of the PEG solution, and was achieved at a seed moisture content below that required for germination (radicle protrusion). Thus all seeds reached the same stage of "suspended animation" before sowing. Different priming conditions have been applied to many species varying the concentrations of PEG (and therefore water potentials used), temperature and timing of treatment. Improvements in the rate and uniformity of germination have been achieved in a range of species (Heydecker \& Coolbear, 1977).

Early priming treatments involved sowing moist seeds immediately after treatment. This led to the improvements observed being described as the result of an advancement of germination (Heydecker $\&$ Coolbear, 1977). However, in some cases when seeds were dried after treatment, some degree of improvement was retained, leading to the suggestion that metabolic repair might also be involved in the response to priming. Subsequently, priming treatments have consistently involved drying the seeds back as this makes subsequent handling and sowing of the seeds easier.

The principle of using controlled hydration in seed invigoration has also been used in a number of other treatments that differ in their means of controlling hydration (Khan, 1992). These include drum-priming (Rowse,1996), solid matrix priming (Taylor et al., 1988), hydropriming (van Pijlin et al., 1996) and aerated hydration (Thornton \& Powell, 1992). In drum-priming, seed moisture content is raised by the addition of a precise volume of water to the seeds whereas during solid matrix priming and hydropriming seeds imbibe until their water potential reaches equilibrium with a moist inert medium or humid atmosphere respectively. These treatments can take up to 14 days. The final method of seed invigoration to be considered here, aerated hydration, was developed at the University of Aberdeen, and 
differs from the others in that it depends on time alone to control the level of seed hydration during a treatment period that is usually less than $36 \mathrm{~h}$.

\section{AERATED HYDRATION INVIGORATION TREATMENT}

Aerated hydration ( $\mathrm{AH})$ hydrates seeds in a column of aerated water up to a moisture content close to that required for radicle protrusion (Thornton $\&$ Powell, 1992). Seeds may be held within the column at this moisture content, but are removed and dried back before radicle protrusion occurs. Initial work on cauliflower and Brussels sprouts seeds (Thornton \& Powell, 1992) identified an $8 \mathrm{~h}$ treatment at $25^{\circ} \mathrm{C}$ as achieving improvements on the rate and uniformity of germination, root growth and seed vigour. However, further work on these species (Thornton \& Powell, $1995)$ illustrated that additional improvements could be achieved by hydration for up to $32 \mathrm{~h}$ at $20^{\circ} \mathrm{C}$. Indeed this raised the vigour of aged, low vigour seeds to become comparable with that of unaged, high vigour seeds. However, this work also showed that if $\mathrm{AH}$ treatment was too prolonged, seed vigour declined.

Improvements in seed quality after AH have also been observed in oil seed rape (Powell et al., 1993) leek, parsnip and carrot (unpublished data). Evidence suggests that the activation of metabolic repair mechanisms is a major contributor to improvements achieved by AH. Thus, the increase in improvement up to an optimum temperature and greater improvement in the presence of oxygen suggest a metabolic process and there is greater improvement of aged seeds in which previously sustained deterioration offers greater potential for invigoration. Such observations are not however restricted to $\mathrm{AH}$ treatments. Brocklehurst \& Dearman (1982) noted that increases in germination rate of carrot, celery and onion after priming were greatest in low vigour (i.e. aged seeds); wheat seeds with intermediate levels of ageing showed the greater response to "flash imbibition", a $2 \mathrm{~h}$ soak in water (Goldsworthy et al., 1982) and Basu and co-workers have observed most improvement in partially deteriorated seeds following a $2 \mathrm{~h}$ soak in water (Basu, 1994).

However, the clearest physiological evidence for metabolic repair during hydration treatments is the increase in the germination observed after the controlled deterioration test following $\mathrm{AH}$ (Thornton \& Powell, 1992). Controlled deterioration (CD) identifies differences in the vigour of seed lots by deteriorating them by the same precisely controlled amount at high seed moisture content and temperature (Matthews, 1980). Seeds therefore move along the seed survival curve during treatment. High vigour seed lots lie near the beginning of the seed survival curve and even after a period of deterioration in $\mathrm{CD}$ they retain a high germination. In contrast, a low vigour lot has previously undergone deterioration and is therefore physiologically older. As a result, deterioration during the $\mathrm{CD}$ test leads to reduced germination after $\mathrm{CD}$. Thus, the increase in $\mathrm{CD}$ germination following $\mathrm{AH}$ implies that $\mathrm{AH}$ has resulted in a seed lot being moved back along the survival curve i.e. a reversal of deterioration. This could be achieved by metabolic repair of previously sustained deterioration. Subsequently, the activation of DNA repair synthesis was shown in Brassica seeds during aerated hydration (Thornton et al., 1993)

Despite the evidence for metabolic repair in aged seeds, the increased rate and uniformity of germination after longer $\mathrm{AH}$ treatments (Thornton \& Powell, 1995), at a point when increases in seed vigour are no longer evident, were indicative of a role for germination advancement in invigoration. Indeed, the improved germination characteristics of high vigour seeds could only be achieved through advancement. The incidence of advancement is also suggested in the results of seed storage studies after invigoration treatment.

Reports of the storage potential of seeds after invigoration treatments have revealed both enhanced and reduced seed storage potential, although the species, treatment, storage conditions and indeed initial seed quality differ from paper to paper (Powell et al., 1997). Recent work on cauliflower seeds has however revealed that the initial seed quality and length of treatment interact to determine the response of invigorated seeds to storage (Powell et al., 1997). Thus after a long (28h) AH treatment, the storage potential of high vigour seeds was reduced when stored at 10 $0 \mathrm{C}$ and $20 \mathrm{OC}$ at both $5.3 \%$ and $12 \%$ moisture content, whereas low vigour seeds had improved storage potential after both a long and short $\mathrm{AH}$ treatment. These responses could be explained by the role of advancement and repair in the two groups of seeds. Thus in high vigour seeds, with little previous deterioration, germination would be advanced during treatment. A prolonged treatment could result in "over-advancement" which increased the seed susceptibility to either the stress of storage or drying after treatment. In contrast, during treatment of low vigour seeds, metabolic repair of previously sustained 
deterioration would occur before germination processes begin. Thus, even after a prolonged treatment, germination would not have advanced too far for the successful storage of low vigour seed. Furthermore, the initial metabolic repair during treatment and the reversal of deterioration would result in treated seeds beginning storage at an earlier point on the survival curve than untreated seeds. Thus low vigour seeds could be successfully stored for longer period following an invigoration treatment.

\section{CONCLUSIONS}

Selection and improvement provide two different approaches to the improvement of seed quality which can be applied at different stages of seed production. In grain legumes, production can be modified to reduce the incidence of cracked testae which leads to imbibition damage and low vigour in some species and seed storage can be carefully controlled and monitored to avoid seed ageing. Seed lots can then be selected for sowing using the electrical conductivity test to identify lots in which imbibition damage and/or ageing have led to low vigour. Thus it is possible to select high vigour lots for sowing in poor conditions. Taking a long term view, selection of testa and/or imbibition characteristics in breeding programmes may also reduce the incidence of low quality seeds. An alternative approach to seed quality improvement is possible in vegetable species through modifying the product of seed production by the use of seed invigoration treatments to enhance seed quality

\section{REFERENCES}

ABDULLAH, W.D.;POWELL, A.A.; MATTHEWS, S. Association of differences in seed vigour in long bean (Vigna sesquipedalis L Fruhw) with testa colour and imbibition damage. Journal of Agricultural Science, v.116, p.259-264, 1991.

ABDULlAH, W.D.; POWELL, A.A.; MATTHEWS, A. Prediction of the storage potential of long bean (Vigna sesquipedalis Fruhw) seed in the tropics. Seed Science and Technology, v. 20, p.142-147, 1992.

ABDULLAH, W.D; POWELL, A.A.; MATTHEWS, S. Prediction and improvement of the storage potential of seeds of Phaseolus vulgaris in the tropics. Seed Research, special volume, p.231-238, 1993.
ASIEDU, E.A.; POWELL, A.A. Comparisons of cultivars of cowpea (Vigna unguiculata) differing in seed coat pigmentation. Seed Science and Technology, v.26, p.211-222, 1998.

BASU, R.N. An appraisal of research on wet and dry physiological seed treatments and their applicability with special reference to tropical and sub-tropical countries. Seed Science and Technology, v.22, p.107-126, 1994.

BROCKLEHURST, P.A.; DEARMAN, J. Interactions between seed priming treatments and nine seed lots of carrot, celery and onion. I Laboratory germination. Annals of Applied Biology, v.102, p.577-584, 1983.

DUKE, S.H.; KAKEFUDA, G. Role of the testa in preventing cellular rupture during inbibition of legume seeds. Plant Physiology, v.67, p.449-456, 1981.

FINCH-SAVAGE, W.E. Influence of seed quality on crop establishment, growth and yield. In: BASRA, A.S. (Ed). Seed quality: basic mechanisms and agricultural implications. New York: Food Products Press, 1994.

GOLDSWORTHY, ; FIELDING, J.L.; DOVER, M.B.J. 'Flash imbibition'- a method for the re-invigoration of aged wheat seeds. Seed Science and Technology, v.10, p. 55-65, 1982.

HEYDECKER, W.; COOLBEAR, P. Seed treatments for improved performance - Survey and attempted prognosis. Seed Science and Technology, v.5, p.353-425, 1977.

HEYDECKER, W.; HIGGINS, J.; GULLIVER, R.J. Accelerated germination by osmotic seed treatment. Nature, v.246, p.42-44, 1973.

KHAN, A.A. Preplant physiological seed conditioning. Hortcultural Reviews, v.13, p. 131-191, 1992.

LEGESSE, N.; POWELL, A.A. Comparisons of water uptake and imbibition damage in eleven cowpea cultivars. Seed Science and Technology, v.20, p.173-180, 1992.

LEGESSE, N. Genotypic comparisons of imbibition in chickpea (Cicer arietinum L) and cowpea (Vigna unguiculata (L) Walp). Aberdeen, 1991. 124p. Thesis (PhD) - Department of Agriculture, University of Aberdeen. 
LEGESSE, N.; POWELL, A.A. The association between the development of seed coat pigmentation during maturation of grain legumes and reduced rates of imbibition. Seed Science and Technology, v.24, p.23-32, 1996.

MATHESON, S. Investigation of the susceptibility of soybean seed to Pythium infection and its fungicidal control. Aberdeen, 1983. 36p. Dissertation (B.Sc.Agriculture) - Department of Agriculture, University of Aberdeen

MATTHEWS, S. A study of seed lots of peas (Pisum sativum L.) differing in predisposition to preemergence mortality in soil. Annals of Applied Biology, v.68, p.177-183, 1971.

MATTHEWS, S. Field emergence and seedling establishment. In: SUTCLIFFE, J.F.; PATE, T.S. (Ed.) The physiology of the garden pea. New York: Academic Press, 1977. p.83-118.

MATTHEWS, S. Controlled deterioration test: a new vigour test for crop seeds. In: HEBBLETWAITE, P.D. (Ed.) Seed production. London: Butterworths, 1980. p.647-660.

MATTHEWS, S.; POWELL, A.A.. Electrical conductivity test. In: PERRY, D.A. (Ed.) Handbook of vigour test methods. Zurich: International Seed Testing Association, 1981. p.37-41.

MORRISON, R.M,; ASIEDU, E.A.; STUCHBURY, T.; POWELL, A.A. Determination of lignin and tannin content of cowpea seeds coats. Annals of Botany, v.76, p.287-290, 1995.

OLIVEIRA, M. DE A.; MATTHEWS, S.; POWELL, A.A. The role of split seed coats in determining seed vigour in commercial seed lots of soyabean, as measured by the electrical conductivity test. Seed Science and Technology, v.12, p.659-668, 1984.

PERRY, D.A. Infection of seeds of Pisum sativum by Pythium ultimum. Transactions of the British Mycological Society, v.61, p.135-144, 1973.

POWELL, A.A. Impaired membrane integrity: a fundamental cause of seed quality differences in peas. In: HEBBLETWAITE P.D.; HEATH, M.C.; DAWKINS T.C.K. (Eds). The Pea Crop: a basis for improvement. London: Butterworths, 1985. p.383-395.

POWELL, A.A. Cell membranes and seed leachate conductivity in relation to the quality of seeds for sowing. Journal of Seed Technology, v.10, p.81-100, 1986.
POWELL, A.A. The importance of genetically determined seed coat characteristics to seed quality in grain legumes. Annals of Botany, v.63, p.169-175, 1989.

POWELL, A.A.; MATTHEWS, S. Deteriorative changes in pea seeds (Pisum sativum L) stored in humid or dry conditions. Journal of Experimental Botany, v.28, p.225-234, 1977.

POWELL, A.A.; MATTHEWS, S. The damaging effect of water on dry pea embryos during imbibition. Journal of Experimental Botany, v.29, p.1215-1229, 1978.

POWELL, A.A.; MATTHEWS, S. The influence of testa condition on the imbibition and vigour of pea seeds. Journal of Experimental Botany, v.30, p.193-197, 1979.

POWELL, A.A.; MATTHEWS, S. The significance of damage during imbibition to the field emergence of pea (Pisum sativum L) seeds. Journal of Agricultural Science, v.95, p.35-38, 1980.

POWELL,A.A.; MATTHEWS, S.; OLIVEIRA, M. DE A.. Seed quality in grain legumes. Advances in Applied Biology, v.10, p.217-285, 1984.

POWELL, A.A.; OLIVEIRA, M. DE A.; MATTHEWS, S.. Seed vigour in cultivars of dwarf French bean (Phaseolus vulgaris) in relation to the colour of the testa. Journal of Agricultural Science, v.106, p. 419-425, 1986a.

POWELL, A.A.; OLIVEIRA, M. DE A.; MATTHEWS, $S$. The role of imbibition damage in determining the vigour of white and coloured seed lots of dwarf French bean (Phaseolus vulgaris). Journal of Experimental Botany, v.57, p.716-722, $1986 b$.

POWELL, A.A.; THORNTON, J.M.; MATTHEWS, S.; YULE, L. Invigoration of oilseed rape (Brassica napus) by aerated hydration. Seed Research, special volume, p.728-733, 1993.

POWELL, A.A; YUlE, L.J.; THORNTON, J.M. Influence of the aerated hydration seed treatment on the response of Brassica seed to storage. In: NATIONAL SYMPOSUIM ON STAND ESTABLISHMENT, 5., Columbus, 1997. Proceedings. Columbus: OARDC, 1987. p.141-149.

ROWSE, H.R. Drum priming - a non osmotic method of priming seeds. Seed Science and Technology, v.24, p.281-294, 1996. 
SEMPLE, F. Investigation of imbibition as a cause of vigour difference in soybean (Glycine max). Aberdeen, 1981. 50p. Dissertation (B.Sc. Agriculture) - University of Aberdeen.

TAYLOR, A.G.; KLIEN, D.E.; WHITLOW, T.H. SMP: solid matrix priming of seeds. Scientia Horticulture, v.37, p.1-11, 1988.

THORNTON, J.M.; POWELL, A.A. Short term aerated hydration for the improvement of seed quality in Brassica oleracea L. Seed Science Research, v.2, p.41-49, 1992.

THORNTON, J.M.; POWELL, A.A. Prolonged aerated hydration for the improvement of seed quality in Brassica oleracea L. Annals of Applied Biology, v.127, p.183-189, 1995.
THORNTON, J.M.; COLLINS, A.R.S.; POWELL, A.A. The effect of aereted hydratation on DNA synthesis in embryos of Brassica oleracea L. Seed Science Research, v.3, p.195-199, 1993.

VAN PIJLIN, J.G.; GROOT, S.P.C.; KRAAK, H.L.; BERGERVOET, J.H.W. Effects of pre-storage hydration on germination performance, moisture content, DNA synthesis and controlled deterioration of tomato (Lycopersicon esculentum Mill.) seeds. Seed Science Research, v.6, p.57-63, 1995.

Recebido para publicação em 10/07/98 Aceito para publicação em 03/08/98 